\title{
EXPLORING INTEREST
}

INTERMEDIATION IN CENTRAL AND
EASTERN EUROPEAN HEALTHCARE

\section{Persistent statism, unfettered pluralism or a shift to corporatism?}

\author{
Michael Dobbins, Emilia Piotrowska, and \\ Maximilian von Bronk
}

\section{Introduction}

How is interest intermediation organized in Central and Eastern Europe (CEE)? Unlike Horváthová and Dobbins (see Chapter 7) who show how interest group-specific factors such as professionalization and expertise help interest groups access policy-makers, we explore the aspect of political coordination and deliberation between the state and organized interests. Also focusing on healthcare, we are interested in whether corporatist-like structures have evolved to balance rivalling interests in Poland, Slovenia, the Czech Republic and Hungary. This question is of great importance because most CEE countries continue to stand out with their overall weak healthcare performance and low life expectancy in European comparison (OECD, 2019). While this clearly also can be attributed to low funding levels, dysfunctional governance structures may negatively impact healthcare outcomes, as reflected in a very critical evaluation by patients themselves (Euro Health Consumer Index, 2019). ${ }^{1}$ Moreover, the support of major interest organizations may also be a crucial prerequisite for passing and implementing successful reforms.

Against this background, we address the following questions: Have corporatist platforms emerged to promote social partnership in CEE healthcare? Do rivalling interest groups consult regularly with the state and one another? To what extent do governments systematically integrate groups with structural disadvantages (e.g. patients or people with disabilities) into decision-making? We first introduce our theoretical framework derived from three ideal types of state-interest group relations - corporatism, pluralism and statism - and discuss existing analyses of state-interest group relations in the region. We then briefly explore the growing literature on corporatist arrangements in healthcare, before deriving a series of indicators to better understand interest intermediation in 
CEE. Based on a large-scale standardized survey, we present our results in Section 4. Drawing on our survey findings, secondary sources and interviews, we conclude with a healthcare "corporatism score" for all countries in Section 5.

\section{State of the art}

Corporatism is a standard analytical paradigm in political science, which aims to grasp systematized negotiations between major social partners. Corporatist systems generally enable the institutionalized integration of privileged organized interests in policy-making and implementation (Christiansen et al., 2010). The term originally emerged from the idea that society should be organized by corporate groups and associations (e.g. agricultural, scientific, economic) to promote social harmony. Ideas based on corporatism became prominent in Fascist Italy and Southern Europe. This "authoritarian corporatism" aimed not so much for social representation and harmony, rather "productivism" to boost industrial production with state-industry pacts (Gagliardi, 2016). After World War II, Western European Christian and social democrats, in particular, pushed for policies based on institutionalized tripartite negotiations between the state and employers' and employees' associations. These emerging forms of "neo-corporatism" (Schmitter, 1985) often resulted in the partial self-management of social spheres by social partners. Such systems strongly contrasted with pluralist systems traditionally characterized by diverse and competing interests, which purportedly bring about a democratic equilibrium (Dahl, 1967).

Targeted efforts to balance socio-economic interests increasingly attracted the interest of political scientists (Korpi, 1983). Schmitter (1974), for example, defined corporatism as a system of interest representation for linking organized interests of civil society with state decision-makers. This coincides with other interpretations highlighting the consensus orientation of corporatist arrangements. For example, Woldendorp defines corporatism as "any form of cooperation between the state and socio-economic interest groups aimed at forging consensus over socio-economic government policies" (1997, pp. 49-50). Along these lines, Müller-Jentsch (1991) understands corporatism as a conflict partnership, whereby the state aims to facilitate compromises by intervention between rivalling organizations. Therefore, neo-corporatism can be any structured relationship between interest groups and public authorities, combining values of cooperation over competition, hierarchy over horizontal social structure (Jacek, 1986, p. 421). Yet, seen critically, neo-corporatist arrangements may also result in the marginalization of social groups and issues, which are poorly organized or not represented by major interest organizations. Schmitter (1989) later addressed this point himself. He highlights that representation monopolies for certain interest organizations are generally crucial ingredients of corporatism, which often goes in hand with official recognition by the state and/or a semi-public status.

Siaroff (1999, p. 177) was arguably the first to lay out concrete indicators to measure corporatism. Defining corporatism as the "[...] co-ordinated, co-operative, 
and systematic management of the national economy by the state, centralised unions, and employers [...], presumably to the relative benefit of all three actors", he spells out 22 components of corporatism in economic policy. These span from strong unionization (with relatively few unions), institutionalized business and labour input into policy-making, their mutual recognition as social partners, to the prevalence of tripartite agreements and consensus-oriented policy-making. ${ }^{2}$ However, Jahn (2016) points out that Siaroff (1999) somewhat convolutes the characteristics of and/or outcomes of corporatism (e.g. small open economies, high social expenditures and successful economic performance). Jahn not only aimed to remedy these deficits, but also included - for the first time - numerous CEE countries in his "corporatism" ranking. He outlines three components: structure, i.e. peak organizations negotiating for their members; function, i.e. arrangements where governments intervene in wage bargaining, whereby unions are heavily involved in governmental decision-making; and scope, i.e. the coordination of wage bargaining and applicability of collective agreements to wider spheres of society. Based on these indicators, Poland and Hungary (along with slightly more corporatist Romania and Bulgaria) received low "corporatism scores", albeit somewhat higher than the United States, Canada and United Kingdom.

\subsection{Post-communist corporatism?}

Aside from the special case of Slovenia (see Stanojević, 2011), the collapse of communism generally heralded the at least partial collapse of trade unions. In the turmoil of the unprecedented political and socio-economic transformation process, trade unions were generally unable to mobilize public support. Other interest groups, many of which were appendages of the communist party, were often viewed with mistrust, resulting in comparatively low associational membership and political participation (Kostelka, 2014). In this regard, Ost argues that trade unions sometimes tended to side with government parties over their own members, because their operations were partially managed by governments (2000). The collective organizational dilemmas of post-communist trade unions and other interest organizations were further compounded by the neoliberal political environment of the 1990s and 2000s, leaving organized labour little room to assert its demands. At least in Hungary and Poland, the 2000s additionally heralded the decline of social-democratic parties, which are generally vocal supporters of corporatist arrangements.

Nevertheless, even in the immediate aftermath of communism, reformoriented governments endeavoured to promote social dialogue, appear more responsive to civil society and more effectively manage social divisions. According to Ost (2000), multiple new platforms for tripartism and civil society engagement emerged in CEE, a trend likely reinforced by the desire to conform with Western European norms (Falkner, 2003). However, Ost shows that such consultative institutions generally failed to fulfil their intended function and instead evolved into informal "pseudo-corporatist" meeting places for social partners. Labour unions were often affiliated with state-owned enterprises, many of which 
underwent privatization, while others proved unable to adapt to the new service economy. Ost goes on to argue that workers often shied away from collective organization out of fear that it would undermine their chances to benefit from the new capitalist economic system (ibid., p. 111). Thus, instead of a functional Scandinavian or Western European-style corporatism, CEE interest intermediation systems - at least in economic policy-making - were characterized by "illusorily corporatist" structures, which often merely served to justify (neoliberal) governmental policy, instead of effectively balancing social partners' rivalling interests. Ost (2011) later re-examined this claim, concluding that tripartism in CEE still produces meagre results and that most of what labour has gained came not from tripartism, rather results from better organization and smarter use of resources.

Olejnik (2020) took Ost's argument a step further with regard to the current "illiberal governments" of Poland and Hungary (see Sata and Karolewski, 2020). He classifies them as "patronage corporatist" to the extent that they actively divide organized interests into allies required for reaching their political objectives and hostile organizations who purportedly lack the "necessary moral authority to advocate for the interests of the citizenry" (ibid., p. 184). Accordingly, governments tend to only engage in political consultations and exchange with social partners with coinciding interests, many of which often directly receive subsidies from the government, while rivalling organizations are actively discredited and combatted. Hence, obedience is rewarded and dissent is sanctioned (Olejnik, 2020).

However, we see two weaknesses in the pre-existing literature on postcommunist corporatism. Aside from Jahn (2016), most pre-existing research remains descriptive and is often not backed up by concrete empirical data. Second, essentially all previous studies are restricted to economic policy (for energy policy, see Horváthová and Dobbins, 2019), a policy area arguably too vast and multifaceted to be fully grasped with existing concepts and typologies. After all, public-private interactions and arrangements may vary not only between policy areas, but also within societal sectors depending on the specific issue or decision process. Thus, in this chapter, we build on and apply various assumptions and concepts put forward in the previous literature to healthcare. Just like the economic sector, healthcare systems may equally be characterized by corporatist social pacts and institutionalized consensus-making.

\subsection{Healthcare interest representation in CEE}

Corporatist traditions historically are directly linked to social and health insurance systems. In fact, the first Bismarckian welfare insurance scheme was devoted to healthcare and aimed to secure social peace based on the idea of transition from "peasants to patients". It is therefore not coincidental that the size, power resources and mobilization of trade unions and patients' organizations are often key variables in explaining the existence of universal health insurance systems. Gerlinger (2009) defines healthcare corporatism as the institutionalized integration of conflicting interests in decision-making, while highlighting the role of 
private interest groups in the formulation and implementation of binding collective rules. In his understanding, healthcare corporatism is based on the relative parity between representatives of the insurance industry, medical profession and patients organized in centralized administrative bodies. Such systems generally are characterized by the co-management by the state, medical profession, patients' organizations, as well as the insurance and pharmaceutical industries. Not least because the globally top-performing healthcare systems exhibit corporatist features (e.g. Norway, Netherlands, Switzerland), scholars have also explored interest intermediation in this area (Zimmer, 1999; Hunter, 2013).

However, interest intermediation in CEE healthcare remains largely unexplored. Initial steps towards healthcare corporatism were taken in the early 1990s in order to secure social peace and amortize transition costs (Ząbkowicz, 2014, p. 12). Post-communist reforms aimed at abandoning the integrated, tax-based Semashko model of state control and establishing Bismarckian-like, compulsory health insurance systems. In addition, those reforms were aimed at decentralization, reducing the size of the hospital sector, introducing private providers, corporatizing public healthcare facilities and improving the quality of care (Rechel \& McKee, 2009; Sześciło, 2017). The birth of health insurance systems in CEE also heralded the emergence of institutions essential for social dialogue and a shift from "governing" into institutionalized "governance". Different countries chose different pathways. Bohle and Greskovits (2012) differentiate between neoliberal arrangements of the Visegrád countries and more neo-corporatist settings in Slovenia. Other scholars argue that CEE countries developed a statist health insurance type, in which state actors are predominant in regulation and governance, while financing is organized by societal actors, and provision delegated to private entities (Böhm et al., 2013). Against this background, we now address to what extent and which organizations are heavily integrated into CEE healthcare policy-making, whether the systems are gravitating towards the corporatist paradigm and how interest intermediation arrangements vary by country (see also Kaminska, 2013).

\section{Methodological approach}

To develop an integrated framework for exploring interest intermediation in CEE healthcare, we first analytically distinguish corporatism from two contrasting concepts: pluralism and statism. Pluralism is characterized by the existence of diverse and competing interests which operate in organizationally fragmented and less integrated interest intermediation systems (Truman, 1951; Dahl, 1967). Instead of power being vested in "peak associations", heterogeneous organizations compete to effectively articulate their demands towards the state (Streeck, 1983). Interests are brought to bear by unstable and fleeting alliances between advocacy groups. While pluralist systems may offer numerous avenues for interest group participation, there are generally few institutionalized consultation platforms with the specific aim of balancing rivalling interests. Thus, interest groups usually operate outside the government through political pressure, personal contacts with actors or 
by parliamentary lobbying (Wilson, 1983, p. 897). In statist systems, by contrast, private interest and advocacy groups are mainly viewed as a disturbance. Instead, a strong, technocratically operating executive generally dominates the policy process without regularly consulting non-governmental stakeholders (Woll, 2009).

To demarcate corporatism from contrasting paradigms, we bind together the above-mentioned concepts and define several "ingredients" of corporatism. In economic policy and beyond, corporatism generally entails the transfer of policy-making away from parliament and the concentration of self-management capacities in "peak organizations". Streeck and Kenworthy (2003) refer to this as the structural aspect of corporatism. Second, the functional dimension (ibid.) sees for strong political coordination and exchange between the state and organized interests. As shown above, corporatist arrangements are also characterized by a distinct consensus orientation and relatively equal representation of diffuse (e.g. patients) and concentrated interests (e.g. medical chamber, hospitals associations). Fourth, corporatist constellations exhibit mechanisms for policy coordination between rivalling interests.

To grasp these aspects, we designed an online questionnaire and contacted all national-level healthcare organizations in Poland, Hungary, Slovenia and the Czech Republic. The survey included numerous open and closed questions regarding their interactions with political parties, governments, regulatory authorities as well as policy coordination with the state and rivalling organizations. The advantage of the survey is that we can gather insights and authentic opinions from interest organizations themselves. National governments or ministries may be inclined to exaggerate the democratic quality and consensus-oriented nature of their political institutions. We received approx. 200 responses from healthcare organizations in the four countries (Czech Republic $\mathrm{N}=68$, Hungary $\mathrm{N}=38$, Poland $N=45$, Slovenia $N=48$ ), and from nearly all major players (e.g. larger patients' groups, medical chambers, healthcare employees). We also conducted numerous interviews with interest groups and analysed official data on existing institutionalized tripartite dialogue bodies as well as unionism in general.

We identify two main ingredients of the functional dimension: institutionalized inclusion of organized interests into policy-making, reflecting a strong culture of consultation and deliberation with the state, as well as consensus-oriented relations between organized interests themselves.

Addressing the first dimension, we asked all organizations about their perception of policy coordination:

How would you rate the level of policy coordination/political exchange between the state and your interest group? (1 - very weak, 2 - weak, 3 - moderate, 4 - strong, 5 - very strong)

We then asked a series of questions about their inclusion into consultations:

Approximately how often does your organization consult with political parties? (1 - never, 2 - approx. annually, 3 - approx. biannually, 4 - monthly, 5 - weekly) 
Approximately how often does your organization consult with regulatory authorities in your field of activity? (1 - never, 2 - (approx.). annually, 3 - (approx.) biannually, 4 - monthly, 5 - weekly)

Furthermore, we are interested in the stability of interest intermediation constellations over time:

Approximately how many times does the (present) government consult interest groups in your field of activity? (1 - never, 2 - (approx.) annually, 3 - (approx.) biannually, 4 (approx.) monthly, 5 (approx.) weekly)

Approximately how many times did the previous government consult interest groups in your field of activity? (1 - never, 2 - (approx.). annually, 3 - (approx.) biannually, 4 - monthly, 5 - weekly)

A high degree of continuity spanning beyond different governing coalitions would indicate relatively stable interest intermediation arrangements and that the government is not just consulting its temporarily preferred interest groups. This aspect comes into play, in particular, with Hungary and Poland, but arguably also with the Czech Republic (Hanley \& Vachudova, 2018), which, according to various observers, have been affected by "democratic backsliding" in the 2010s (Sata \& Karolewski, 2020). This also enables us to explore Olejnik's (2020) argument about "patronage corporatism" under "populist" governments.

To address the second ingredient of functional dimension, namely consensusoriented relations between organized interests, we first asked two questions:

Do you think that opportunities for participation in the policy process are equally distributed among interest organizations? (1 - very much to the favour of other organizations, 2 - somewhat to the favour of other organizations, 3 - equally distributed, 4 - somewhat to the favour of our organization, 5 - very much to the favour of our organization)

To what extent do you assess the ability of your organization to assert its interests? (1 - very low, 2 - low, 3 - somewhat, 4 - high, 5 - very high)

As corporatism generally entails a strong degree of political exchange and coordination between rivalling interests instead of open political competition, we asked:

Approximately how often does your organization consult with interest groups representing opposing interests in your area of activity? (1 - never, 2 - (approx.) annually, 3 - (approx.) twice a year, 4 - (approx.) monthly, 5 - (approx.) weekly)

We identified three main "ingredients" for the structural dimension: the transfer of policy-making away from parliament, existence of a regular interest intermediation body with a platform devoted to healthcare issues, a representation 
monopoly for certain encompassing organizations, and the existence of selfmanaged, peak organizations of capital and labour (see below).

\section{Empirical analysis}

We broke down all responding healthcare organizations into subgroups based on structural features and focus of activity. We divided the organizations into "small organizations" (fewer than 500 members or 50 member institutions), "large organizations" (500 members or more and 50 institutional members or more), "umbrella organizations", "non-umbrella organizations". In pluralist constellations, one would normally expect smaller organizations to have relatively equal access to decision-making bodies, whereas corporatist structures are generally characterized by representation monopolies of larger, encompassing "umbrella" organizations. Regarding their focus, we divided the organizations into "medical profession", "patients' groups", "health employees" and "employers' and employees' organizations". 3

We also engage with the scholarly debate on public and state funding of interest groups. Some scholars argue that public funding negatively influences interest groups' autonomy, while others contend that it boosts their access and participation (Crepaz et al., 2019). We therefore created a list of state-subsidized organizations. This also includes EU funds for healthcare, which are generally managed and distributed by the member states themselves (Nicolaides, 2018). In fact, Crepaz and Hanegraaff (2020) argue that many organizations would cease to exist without the EU funding.

Our survey respondents provide data on both national government subsidies and EU funds (allocated via national governments) which we both treat as state subsidies. We therefore set a threshold of at least 20\% of organizations' budgets (both from national governments and EU subsidies) ${ }^{4}$ to classify them as the “subsidies group". This enables us to test Olejnik's (2020) argument that illiberal governments are giving incentives and privileges to certain organizations in exchange for political support.

\subsection{Functional dimension of corporatism}

All countries reported a low policy coordination and exchange with the state, especially Slovenian organized interests. Hungarian organizations, in general, report a somewhat higher level of political coordination than their Polish and Czech counterparts.

We would interpret the low aggregated score for Slovenia potentially as a reflection of corporatism, as the scores for the many responding smaller organizations likely watered down the overall score. Looking at umbrella organizations, we see a significantly higher score pointing to the existence of steady representation arrangements. 


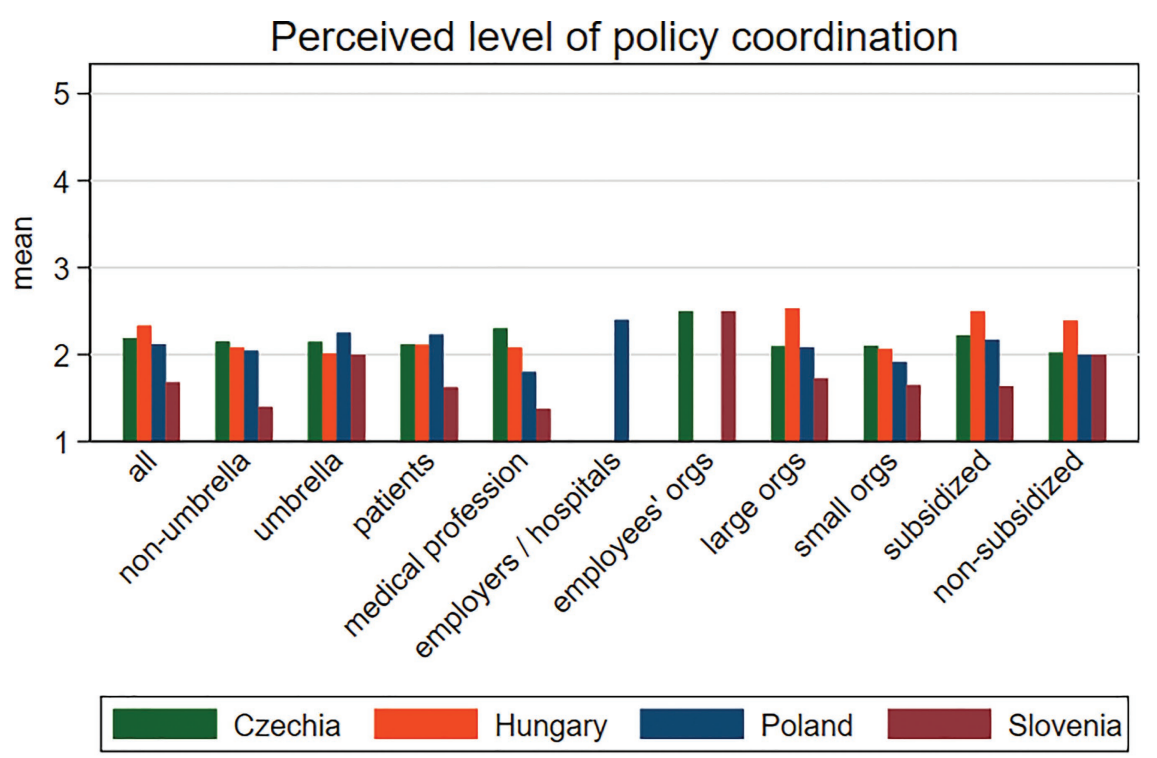

Note: 1 - very weak, 2 - weak, 3 - moderate, 4 - strong, 5 - very strong.

FIGURE 5.1 Perceived level of policy coordination.

We then measured the intensity of consultations between groups of interest associations and political parties in general. For Hungary, we observe an extremely low level of interactions with political parties. Not even umbrella, large or employers' organizations reported consulting with parties more than once annually. Polish organizations report more frequent political consultations, with a clear bias towards employers' associations. In Slovenia, umbrella, large employees' organizations (trade unions) report relatively frequent consultations with political parties from once to twice a year, while non-umbrella, employers' and medical organizations almost never consult with parties. The reason could be that many Slovenian medical profession organizations view themselves as "apolitical organizations", as reflected in numerous survey responses, whereas larger umbrellas and employees' organizations consult with parties more often. The Czech situation is markedly different, where at least large umbrella organizations, employers'/hospital organizations and employers relatively frequently engage with political parties.

As an indicator for the corporatist self-management of the healthcare sector, we measured the intensity of consultations with regulatory authorities. In all respective countries, both large and umbrella organizations consulted with regulatory authorities more frequently than others. Poland reported the most frequent consultations, together with Hungary exhibiting a small bias towards umbrella organizations and employers' organizations, whereas patients' organizations and the medical profession score rather low. In the Czech Republic, large groups 


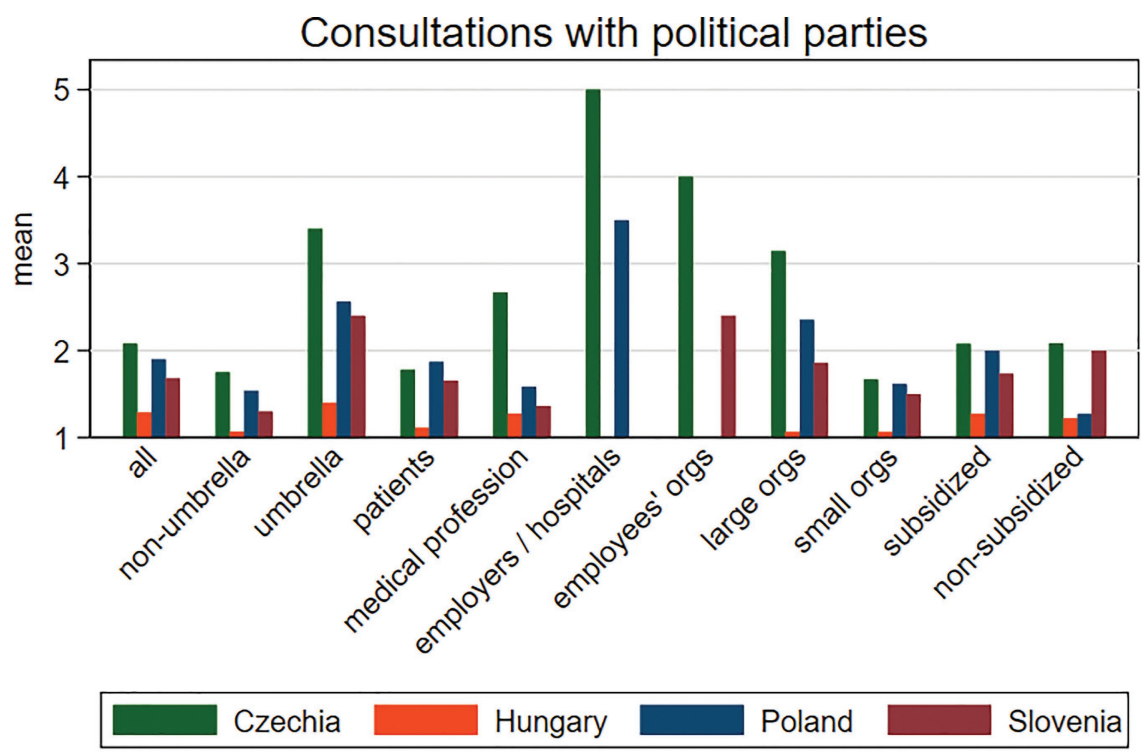

Note: 1 - never, 2 - (approx.) annually, 3 - (approx.) twice a year, 4 - (approx.) monthly, 5 - (approx.) weekly.

FIGURE 5.2 Consultations with political parties.

demonstrated the highest score. Slovenian organizations again seem to exhibit an aversion to the political process. Instead of regularly consulting parties, employees' organizations (trade unions) consult with regulatory authorities on a monthly basis, while large organizations indicate a moderate level (at least twice a year). Small and medical profession organizations rarely consult them though.

Assuming that corporatist arrangements remain stable over time, we compared the intensity of consultations between the present governments (Poland $=$ the moderately national-conservative PiS government, 2015-present; Hungary = the strongly national-conservative Fidesz government, 2010-present; Slovenia = the centre-left LMŠ (Lista Marjana Šarc), 2018-March 2020; Czech Republic = the liberal Ano / Social Democratic ČSSD government, 2018-present) and previous governments (Poland = Civic Platform (PO) (2007-2015); Hungary = socialist MSZP - liberal SZDSZ (2004-2010); Slovenia = centre-right SDS (2014-2018); Czech Republic= ĆSSD / Ano \& Christian Democratic KDU-ČSL (2014-2018)).

For Poland, we observe no change in policy style between the liberal PO government (2007-2015) and the national-conservative PiS government (2015present). If anything, the current PiS government appears slightly more open to consultations with organized interests than the previous government, especially towards employees' and umbrella organizations. In fact, we even see - at least for this indicator - a slight advantage for patients' organizations, which are traditionally more difficult to organize than professional interests. This was confirmed by one large umbrella patients' organization in an interview (July 2019) which cited the PiS government as being very open to consultations. Figure 5.4 only 


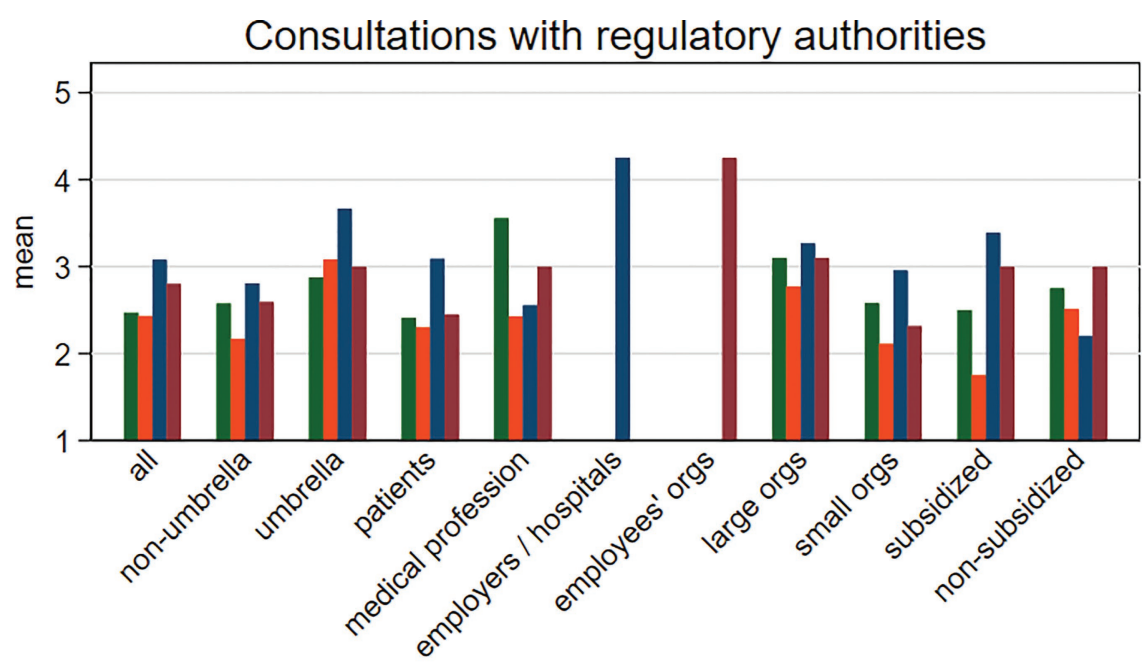

Czechia

Hungary

Poland

Slovenia

Note: 1 - never, 2 - (approx.) annually, 3 - (approx.) twice a year, 4 - (approx.) monthly, 5 - (approx.) weekly.

FIGURE 5.3 Consultations with regulatory authorities.

Consultations with present and previous government: Poland

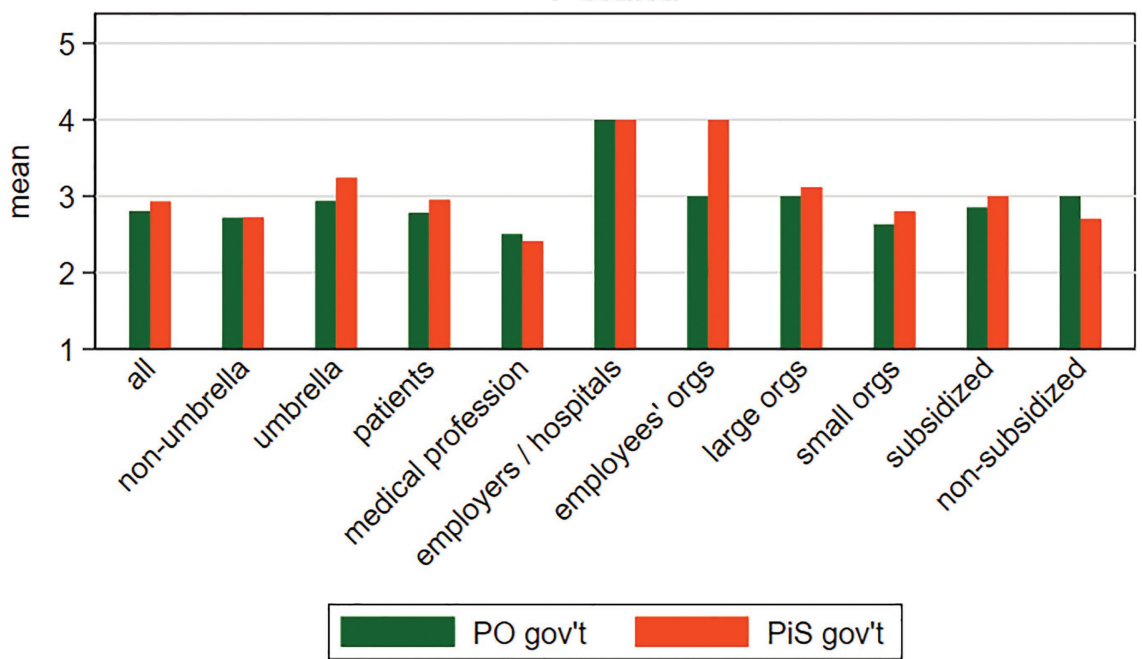

Note: 1 - never, 2 - (approx.) annually, 3 - (approx.) twice a year, 4 - (approx.) monthly, 5 - (approx.) weekly.

FIGURE 5.4 Consultations with present and previous government: Poland. 
lends very slight evidence to Olejnik's "patronage corporatist" argument that national-conservative governments give preferential treatment to organizations, which they subsidize.

For Hungary, our findings also reflect stability. However, we do see a slight decline in consultations with patients and increase with the medical profession, a finding also confirmed by respondents' comments. Returning to Olejnik's argument, we see at best a minimal difference between subsidized and nonsubsidized organizations.

Slovenian healthcare associations more frequently consult with the present government than the previous (centre-right) government.

For the Czech Republic, we see slightly more frequent consultations with the present Babiš government than before, especially for patients' organizations, and also slight preferential treatment of organizations receiving state subsidies.

Our next illustrations reflect the views of interest organizations on their opportunities for political participation and their perceived influence. Apart from few exceptions, such as Polish small and large organizations, we see no major difference in perceived equality of opportunity for political participation regarding concentrated and diffused interests. All Czech groups of organizations reported being disadvantaged. In Hungary, government-subsidized organizations also seem themselves at a clear advantage over non-subsidized organizations, lending some evidence to Olejnik's claim (2020). In Slovenia, healthcare organizations, in particular, employees' and umbrella organizations, generally perceive their opportunities for political participation as relatively equally distributed, whereas patients report being disadvantaged in comparison with both other domestic organizations and their counterparts in the other CEE countries. Interestingly,

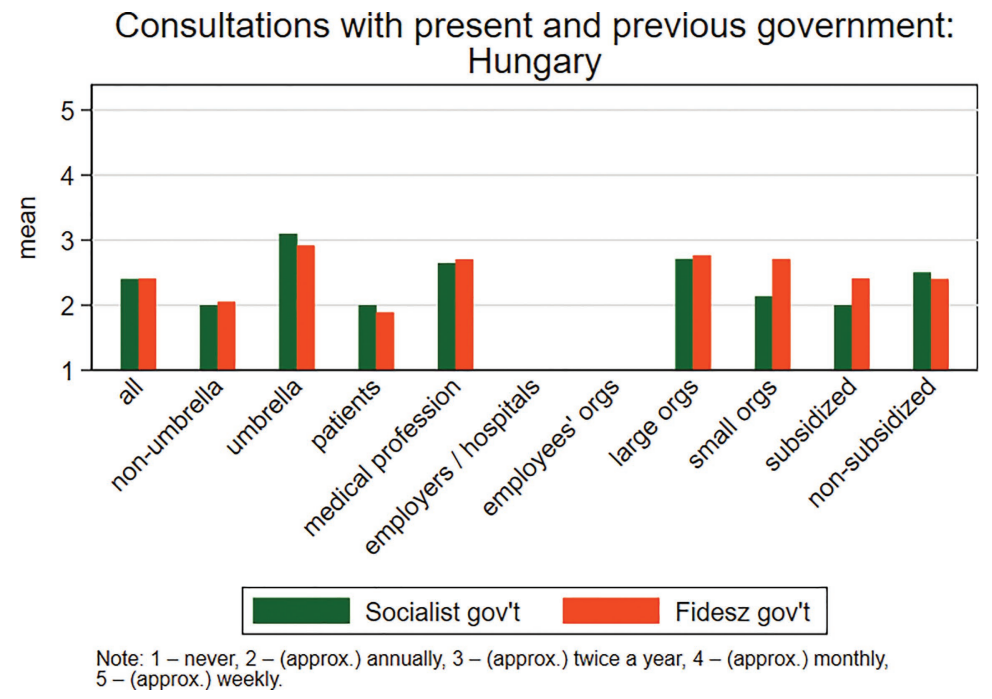

FIGURE 5.5 Consultations with present and previous government: Hungary. 


\section{Consultations with present and previous government: Slovenia}

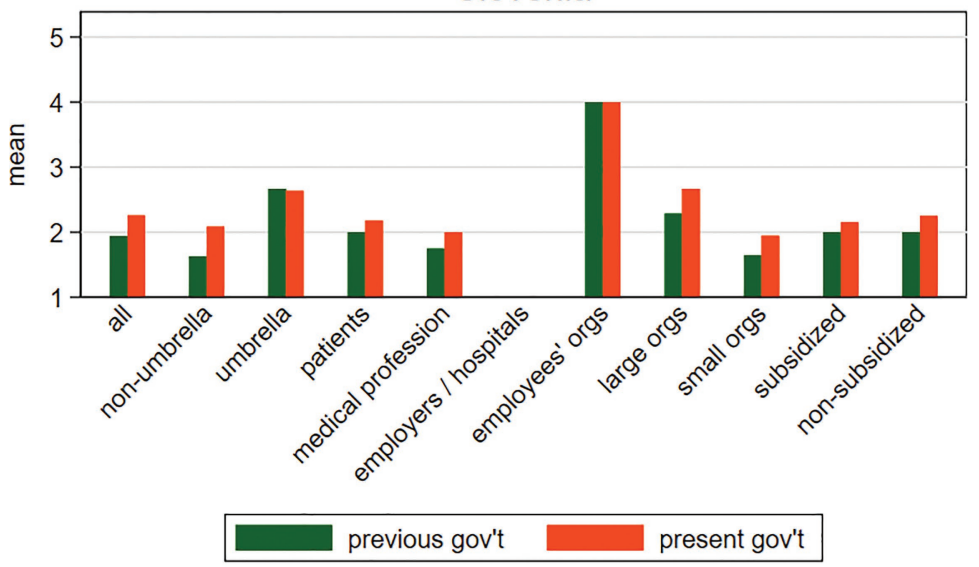

Note: 1 - never, 2 - (approx.) annually, 3 - (approx.) twice a year, 4 - (approx.) monthly, 5 - (approx.) weekly.

FIGURE 5.6 Consultations with present and previous government: Slovenia.

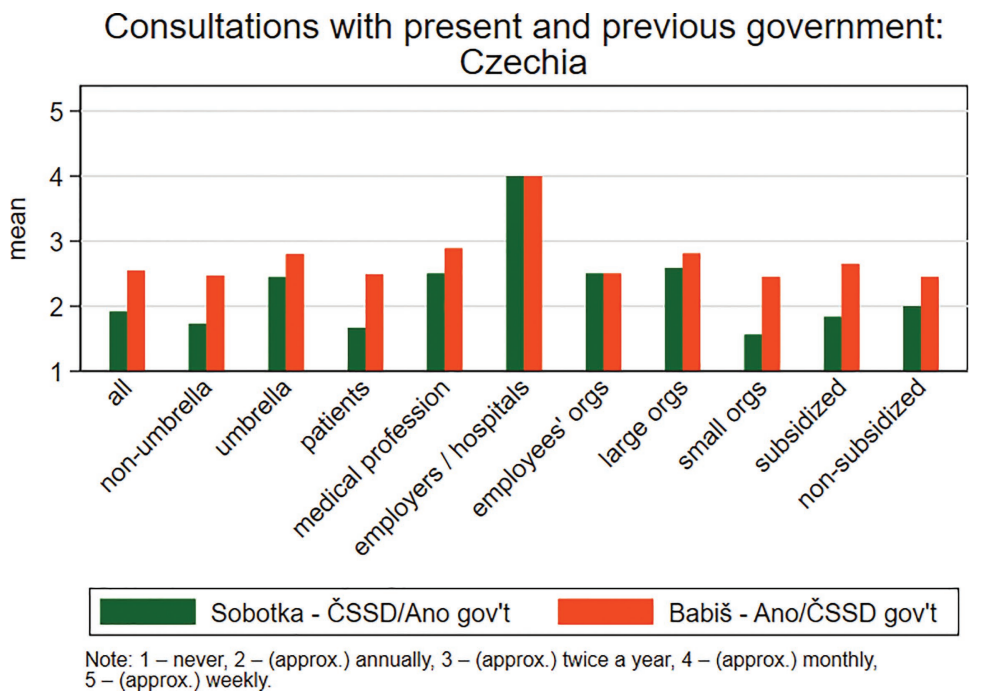

FIGURE 5.7 Consultations with present and previous government: Czechia.

non-subsidized organizations assess their opportunity structures more favourably than government-funded organizations.

Figure 5.9 offers a mixed bag of partially eye-catching findings. In Poland and the Czech Republic, no group of organizations viewed its ability to assert its interests as low. In fact, in all four systems, patients see themselves as equally or even more assertive than medical organizations. The Polish system seems to 


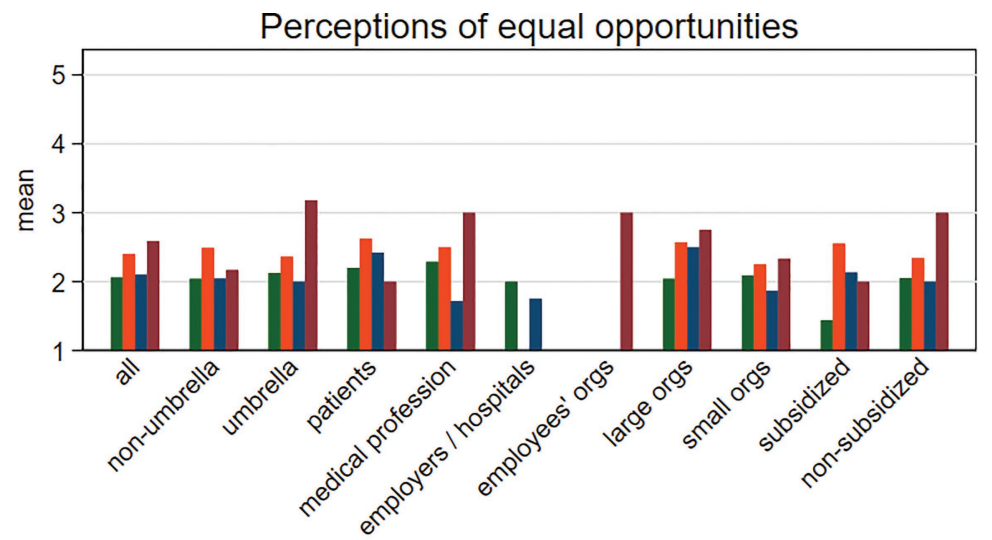

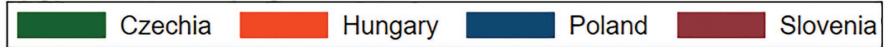

Note: 1 - very much to the favor of other organizations, 2 - somewhat to the favor of other organizations, 3 - equally distributed, 4 - somewhat to the favor of our organizations, 5 - very much to the favor of our organizations.

FIGURE 5.8 Perceptions of equal opportunities.

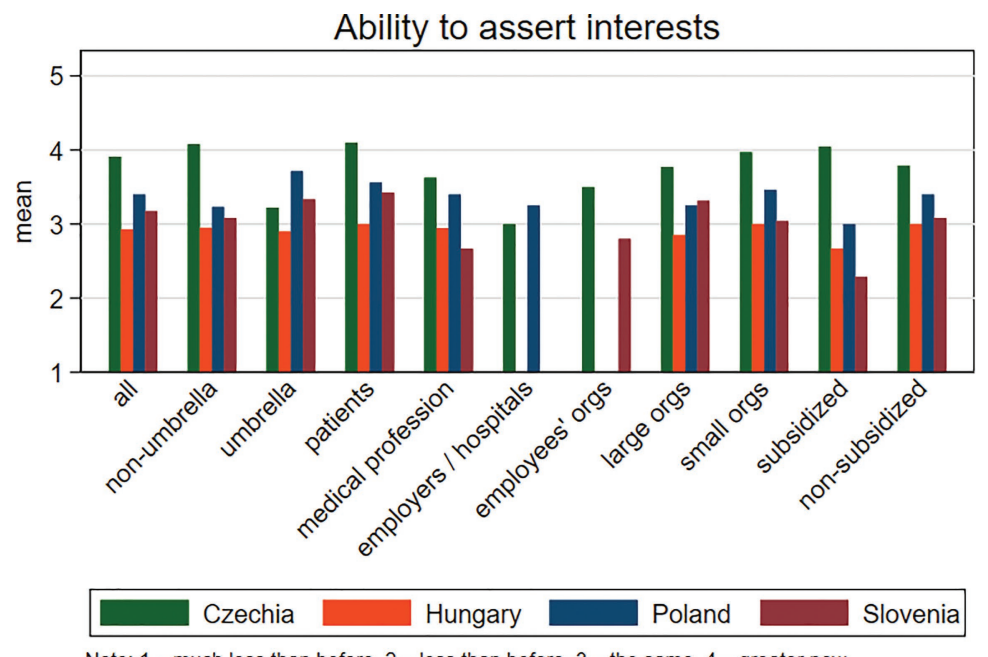

Note: 1 - much less than before, 2 - less than before, 3 - the same, 4 - greater now, 5 - much greater now.

FIGURE 5.9 Ability to assert interests.

better balance the interests of groups with diverse focuses and sizes, whereby our data contradict Olejnik's argument of an advantage for subsidized organizations. The situation with the Czech Republic is also quite interesting: while all groups report being disadvantaged vis-à-vis other interest groups, they all also report a moderate to high ability to assert their interests in policy-making.

Finally, we explored whether CEE organizations engage in consultations with rivalling groups. Hungary stands out here. While nearly all Polish, Slovenian 


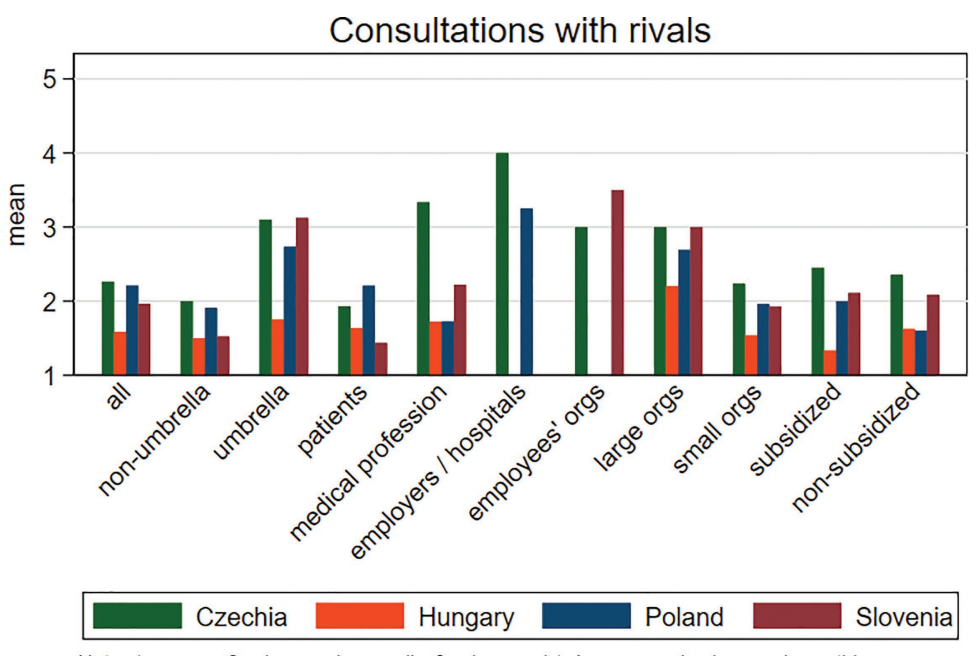

Note: 1 - never, 2 - (approx.) annually, 3 - (approx.) twice a year, 4 - (approx.) monthly, 5 - (approx.) weekly.

FIGURE 5.10 Consultations with rivals.

and, in particular, Czech (groups of) organized interests report at least annually or biannually consultations with rivalling interest groups, Hungarian organizations do not frequently coordinate with one another, pointing to a more statist mode of policy-making. In line with the corporatist paradigm, in the other countries, employers' associations as well as various other umbrella organizations operating in the healthcare sector more frequently interact with organizational rivals, while Hungarian organizations seem to only engage with the state.

\subsection{Structural dimension of corporatism}

Now, we explore the forums in which consultations take place. Is decisionmaking transferred away from the parliament? Do intermediate coordination bodies exist? And do certain groups hold representation monopolies within them and elsewhere? To assess whether the organizations tend to engage in parliamentary lobbying, which is less typical of corporatist systems, we asked:

How would you describe your level of participation in parliamentary hearings/parliamentary committees? (1 - very weak, 2 - weak, 3 - moderate, 4 - strong, 5 - very strong)

We found considerable variation by country. Most Polish organizations report a moderate level of parliamentary participation, and patients' and other diffused groups, such as non-umbrellas, even high participation, shedding doubt on the presence of corporatist structures, whereas Hungarian organizations are essentially not active in the parliament. Slovenia, by contrast, exhibits lower 
parliamentary participation, an observation which also appears to apply to the Czech Republic, albeit to a lesser extent. In both countries though, healthcare employees are frequently involved in parliamentary hearings.

However, the disadvantage of the approach up to now is that aggregating organizations into groups makes it difficult to identify specific organizations frequently engaged in political consultations, i.e. acting as peak organizations. In other words, the aggregate scores of diverse organizations by type may water down the impact of "outliers", i.e. organizations with "representation monopolies".

To further grasp the structural dimension of corporatism, we took two further steps. Regarding intermediate governing bodies and the overall institutional set-up, we relied on survey responses to open questions, interviews and desk research. Then, we constructed a country-specific variable for "representation monopolies" to reflect specific organizations' negotiation position. To do so, we aggregated all scores for all organizations for the frequency of "government consultations", "consultations with parties" and "consultations with regulatory authorities" into one score per organization. For annual consultations, we gave each organization one point, for biannual consultations two points, for monthly consultations 12 points and for weekly consultations 52 points to roughly reflect the approximate frequency of actual consultations. Organizations not involved in any consultations are not included. For reasons of anonymity of our survey responses, we only indicate the areas of activity of the "major players" in each country.

\subsubsection{Czech Republic}

In the Czech Republic, the Ministry of Health plays a strong regulatory role, while the Council of Economic and Social Agreement of the Czech Republic (RHSD) was founded in 1990 to channel the dialogue between the government, trade unions and employers (Navratil \& Pospisil, 2014). A Working Group on Health Care operates within this institution. The health insurance system is based on seven funds, all of them governed within the tripartite system. Medical professionals are organized within chambers on compulsory basis as well as other voluntary organizations. The most prominent is the Czech Medical Chamber, despite limited support from its members (Kafonkova, 2007). The biggest healthcare trade unions, such as the Trade Union of Doctors and Union Association of Health and Social Care, negotiate wages in collective contracts with employers. The main politically active umbrella patient organization is the Czech Association of Patients.

Despite these apparent efforts to formally establish a more corporatist mode of policy-making, numerous indicators in our data point in a more pluralistic direction. First, we see larger, umbrella organizations mainly focusing their activities on political parties (see Figure 5.2) and, to a lesser extent, the parliament (Figure 5.11), while others, in particular patients, only seem to occasionally be 


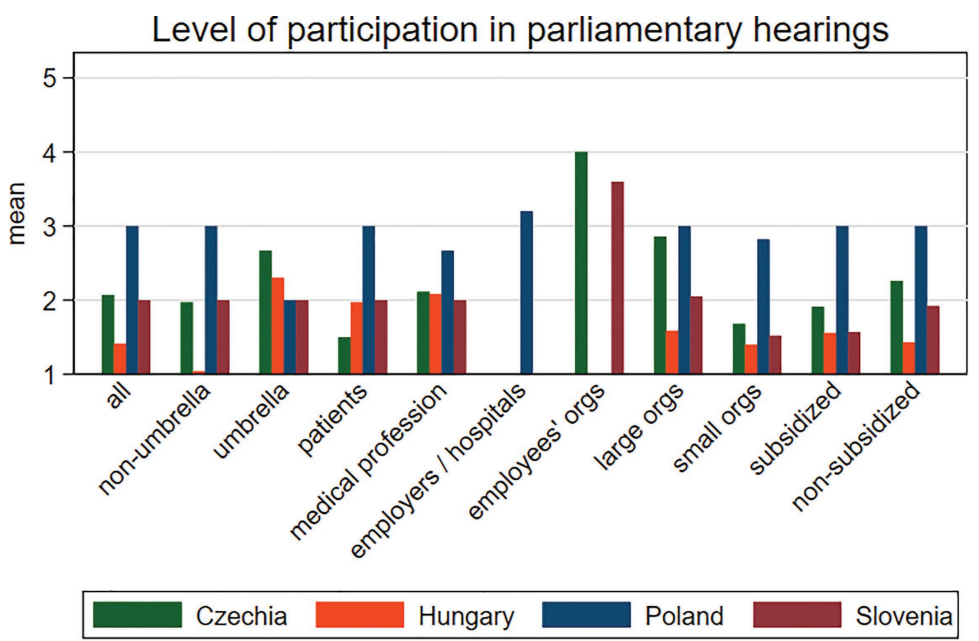

Note: 1 - no participation, 2 - low participation, 3 - occassional participation, 4 - high participation, 5 - very high participation.

FIGURE 5.11 Level of participation in parliamentary hearings.

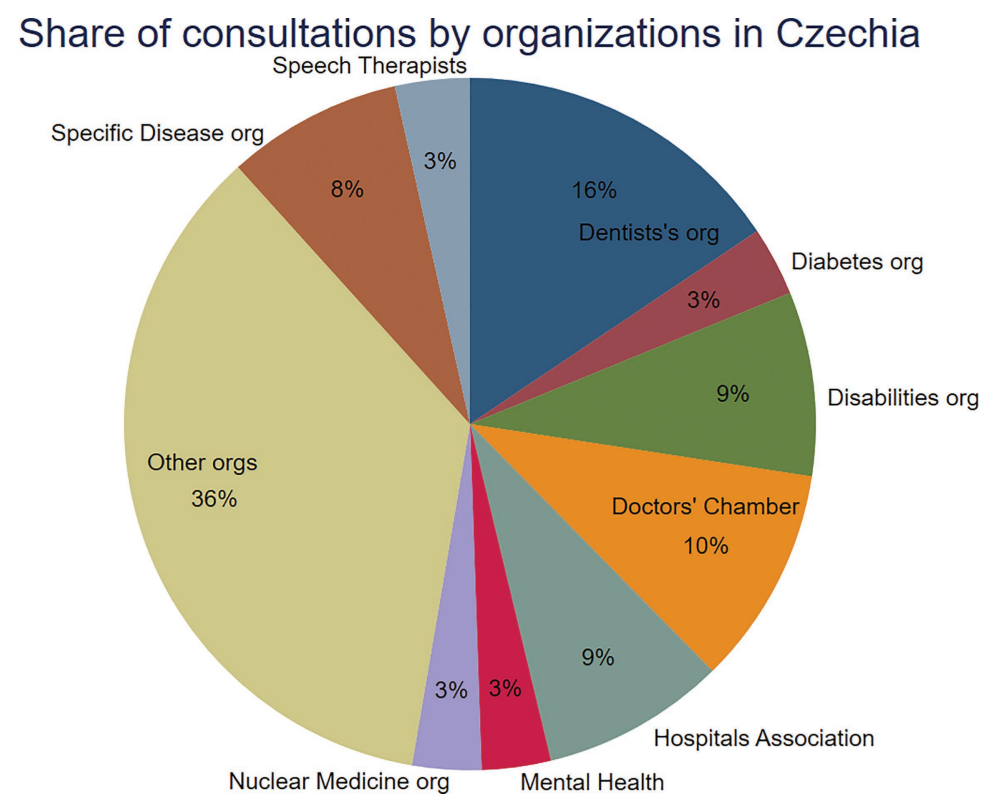

FIGURE 5.12 Share of consultations by organizations: Czech Republic.

included. This is also reflected in our "consultation score". Based on data provided for each organization per country, we calculated its total share participation in all total annual consultations, giving us an overview of which groups are most heavily involved. 
Here, we see seven or eight organizations representing different fields of medicine and hospitals most heavily involved, whereas a highly pluralistic array of patients' groups and other groups occasionally consult with the state. Nevertheless, Figure 5.9 shows that they are relatively successful in asserting their demands despite the lacking representation monopoly of a large umbrella organization. This again supports Roberts' finding (2009) that Czech political parties are highly open to civil society input and relatively quick to embrace their positions, but sheds some doubt on the institutionalization of corporatist structures including all key stakeholders.

\subsubsection{Hungary}

In Hungary, in 1980s, several new trade unions, professional and scientific associations were established, replacing the communist healthcare trade union. The largest were the Health Workers' Democratic Union, the Federation of Hungarian Medical Societies and the Hungarian Medical Chamber. In the 1990s and 2000s, patients' associations grew in numbers and influence. Their participation was institutionalized in waiting list committees, in the National Health Council, in regional health councils and in hospital supervisory councils (Gaal et al., 2011). Today, a single health insurance fund provides coverage for the population, whereby the government exerts strong control over healthcare policy. The Ministry of Human Capacities administers the system through the National Healthcare Service Centre (ÁEEK). The parliament is responsible for determining the size of the health insurance budget. Since 2010, Hungary returned to the model of a single, monopolistic, government-friendly union confederation(s), followed by decentralized collective bargaining and union structures. This is a sign of a decline of tripartite corporatism (Neumann \& Toth, 2018). In healthcare, which largely remains under governmental control, the power and density of trade unions are relatively higher than in other sectors. Currently, there is no tripartite social dialogue in the public sector in Hungary. The National Economic and Social Council (NGTT, Nemzeti Gazdasági és Társadalmi Tanács), founded in February 2012, consists of the representatives of trade unions, industry chambers, various social and scientific organizations and even churches. It is not a consultative body as government representatives are merely observers on its sessions, and it can only draft proposals for the government. However, no patients' organization is formally included, an observation also reflected in Figure 5.13.

Breaking down the share of consultations by individual organizations, it appears that many responding organizations (approx. 20) essentially never negotiate with the state (not shown in pie chart). In line with the literature cited above, we see a strong presence of trade unions, as some four or five groups primarily representing the medical profession appear to have a quasi-monopoly status in negotiations with the state. 


\section{Share of consultations by organizations in Hungary}

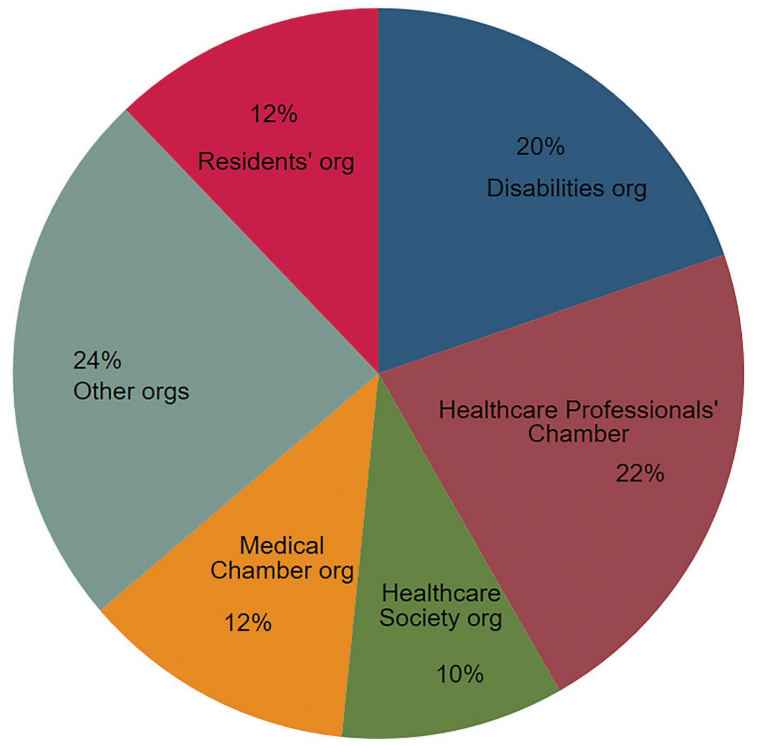

FIGURE 5.13 Share of consultations by organizations: Hungary.

However, other than one organization representing patients with disabilities, both general and specific patient groups appear to be consulted seldom or never, a finding also confirmed by two responding large patients' organizations who claim to be never included in dialogue or substantially consulted by the government (May 2020; June 2020).

\subsubsection{Poland}

In Poland, healthcare governance - based on social health insurance - appears to be "a bit of everything". The system is itself much more fragmented than the Hungarian system, as the Polish Ministry of Health shares governance duties with three levels of territorial self-governments. The state holds strong regulatory, budgetary and managerial powers, while corporate actors are not accorded a significant role in healthcare regulation (Wendt et al., 2013). The system relies on statutory health insurance with a growing role of the private sector.

Our data paint a relatively pluralistic picture regarding the share of consultations by organization. Here, we see two large employers' organizations heavily involved in political consultations, but also frequent negotiations with various patients' organizations and those dealing with specific diseases.

Under Law and Justice (PiS), many reforms were adopted, generally aimed at centralization and potentially heralding a shift towards more statist interest intermediation (Szęściło, 2017). Poland also introduced in 2015 a tripartite dialogue 


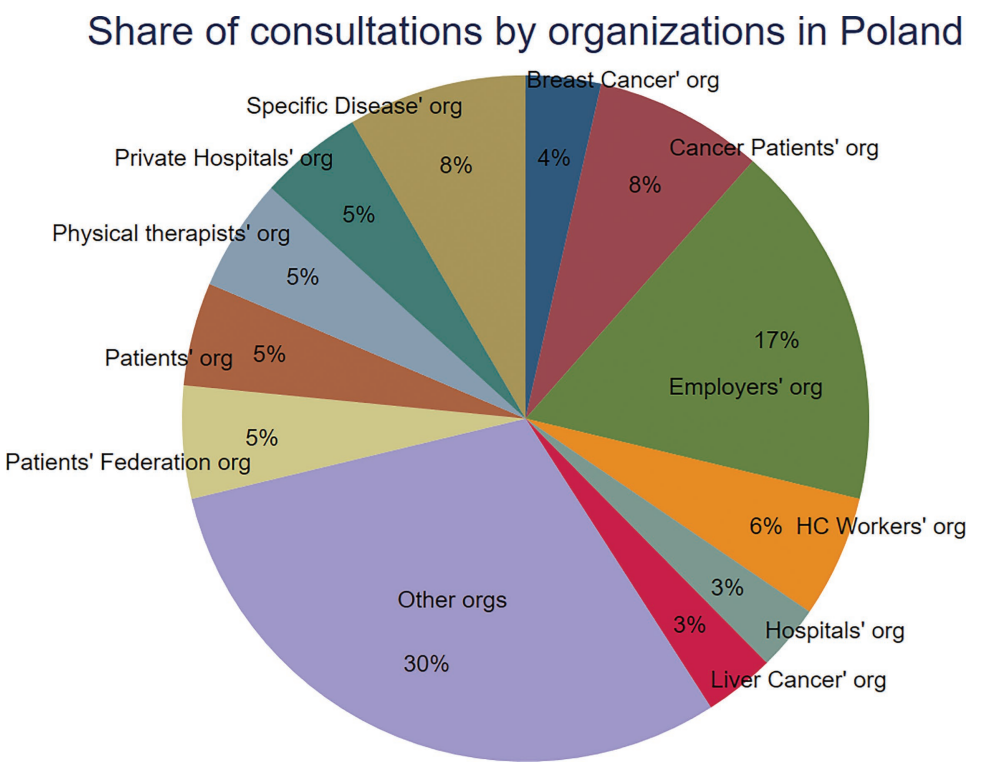

FIGURE 5.14 Share of consultations by organizations: Poland.

body, Rada Dialogu Społecznego (Social Dialogue Council - RDS), which was indicated by various responding employers' organizations to be an important forum. However, our data show that patients' organizations continue to target the parliament (see Figure 5.11). Thus, the RDS seems to have further consolidated the already existing situation of intense consultations with the employers' side to the neglect of the patients' side. Therefore, healthcare policy-making seems to be very fragmented due to the scattered authority between the government and local governments as well as the openness of parliamentarians to discussions with the social stakeholders and interventions by the Ministry of Health. Many actors with non-peak status seek other points of contact, for example, Senior Councils (representing older people), whose advisory and consultative role in local healthcare decision-making is growing (Frączkiewicz-Wronka et al., 2019).

However, there are some contrary observations. In 2017, the Junior Doctors' initiative carried out a hunger protest with a series of demands, including raising their salaries and increasing public expenditures for healthcare. During the protest, a treaty of all medical professions was signed. At first ignored by the government, strikes spread quickly among residents and specialists (Polak et al., 2019). In order to strengthen their bargaining position, Junior Doctors joined the Nationwide Trade Union of Doctors (OZZL) and succeeded in achieving their goals. Even though OZZL is not formally part of RDS, the umbrella of a large, representative professional organization facilitated the negotiations. This showed that despite declining trade union power and density in general, institutionalized trade union umbrellas and bureaucracy still matter in healthcare. 


\subsubsection{Slovenia}

The Slovenian political system offers healthcare interest groups numerous important points of access. It is unique to the extent that the National Council (Drzavni svet) functions directly as the representative of organized interests of a socio-economic, professional and local character within the legislative system. It does not write or block legislation itself; rather its elected "councillors" from academic, civil society and healthcare have a corrective function in the legislative process. Medical professionals are traditionally gathered in medical chambers that administer and regulate their licensing, continuous education and training, as well as voluntary NGOs, such as the Slovenian Medical Association.

In 1994, as a result of an agreement on wage policy, the Economic and Social Council (ESC) was also established and still functions as an important tripartite body for social partners and the government. Within the ESC, the Committee on the Organization of the State and Public Affairs address issues regarding healthcare policy. The social health insurance system, operated by a single purchaser, is backed by the voluntary, supplementary insurance with almost full coverage of the population. The system is relatively centralized with a leading role of the Ministry of Health and National Council at various stages of decisionmaking, as indicated by various survey respondents. Social partners play a dual role in welfare state matters: an advisory role through the ESC and an administrative role through their own representatives in the tripartite boards of the Institute for Pension and Disability Insurance (IPDI), the Health Insurance Institute of Slovenia (HIIS) and the Employment Service of Slovenia (ESS) (Albreht et al., 2016). Several trade unions represent the interests of health professionals, such as the Slovenian Union of Physicians and Dentists, the Slovenian Health Service and Social Service Union, the Federation of Slovenian Free Unions (Healthcare

and Social Care Union Department) and the Union of Healthcare Workers of Slovenia. Several health-related NGOs are active in the system. Patient organizations are often invited to participate in the drafting of policies and regulations in their specific area. However, there is no umbrella organization representing organized patients' interests (Bugaric \& Kuhelj, 2015).

Looking at the share of consultations by organization, Slovenia presents the most balanced picture of our four countries and largely reflects the considerations above, with healthcare workers, professionals, administrators and the medical professions being relatively equally represented. However, the survey data also reflect the lack of a large patients' organizations, rather a multitude of smaller, specialized patients' organizations (not labelled) who are able to make themselves heard.

\section{Comparative corporatism scores}

What do all these data tell us? Following Jahn's (2016) lead, we calculated a "corporatism score" for healthcare policy-making in each country taking all the survey results and our broader research into account. To do so, we defined ten 


\section{Share of consultations by organizations in Slovenia}

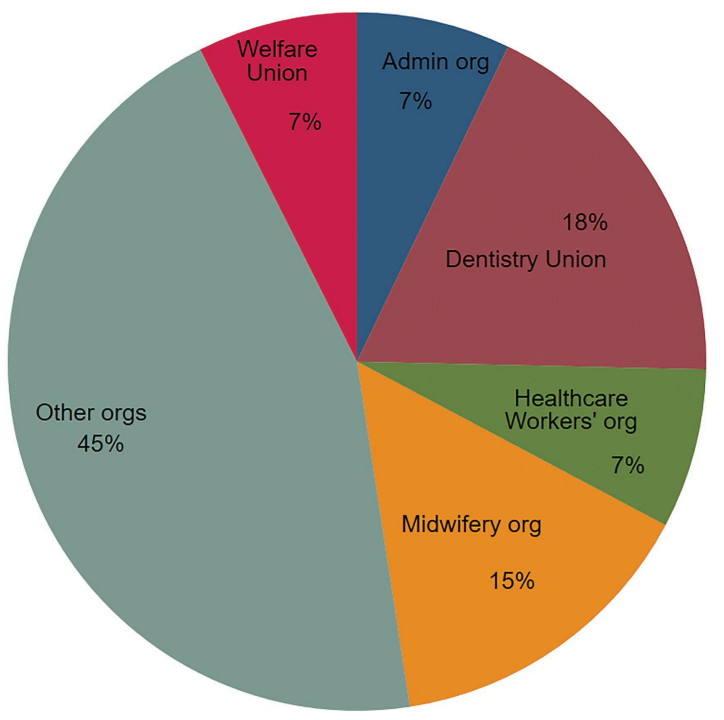

FIGURE 5.15 Share of consultations by organizations: Slovenia.

indicators for the functional and structural dimensions with a maximum score of 5 points, resulting in 50 as a maximum value.

For the functional dimension, we calculated the average scores for all organizations for the following variables on a 1-5 scale: perceived level of policy coordination, consultations with political parties, consultations with regulatory authorities, consultations with the present and previous government. Regarding the latter, to grasp the stability over time, we opted to award 1 or 2 points for a decrease in the stability of consultations, 3 points for no change and 4-5 points for an increase in consultations. Regarding consensus-oriented relations between organized interests, we included the score for "consultations with rivals" of all organizations on 1-5 scales, again based on the survey outcomes. Assuming that patients' organizations are traditionally at a structural disadvantage, we calculated patients' "perception of equal opportunities".

Then, we looked at the structural dimension by assessing whether a regular institutionalized intermediation body exists. In each country, except for Hungary, we identified an institutionalized, tripartite consultation platform with a healthcare working group operating within in: i.e. Czech Republic the Tripartita - Council of Economic and Social Agreement (RHDS), Poland Social Dialogue Council (RDS), Slovenia - Economic and Social Council (ESS). Here, based on secondary literature and survey comments, we granted maximum 5 points: one for the existence of a tripartite body, one for the existence of a healthcare dialogue platform within the body, then one for the inclusion of patients' representatives and from 1 to 2 points depending on the number of health-related topics on the political agenda (number of health-related meetings). ${ }^{5}$ 
Then, we used our survey question regarding parliamentary lobbying (1-5 points) as a sign of non-corporatist policy-making. The scores were reversed from the original values in the survey: the higher the parliamentary access per country, the fewer corporatism points given. To reflect representation monopolies of certain encompassing organizations, we calculated what share of all annual consultations the most frequently consulted groups ${ }^{6}$ participate in, and transposed this number to a $1-5$ scale.

Our aggregate "corporatism score" shows Slovenia in the lead, with almost $60 \%$ of possible points. This is a result of a combination of the existence of

TABLE 5.1 "Corporatism score" in CEE healthcare policy-making

\begin{tabular}{|c|c|c|c|c|c|c|c|}
\hline Dimension & Ingredient & Variable & $\begin{array}{l}\text { Czech } \\
\text { Republic }\end{array}$ & Hungary & Poland & Slovenia & $\begin{array}{l}\text { Max. } \\
\text { value }\end{array}$ \\
\hline \multirow[t]{7}{*}{ Function } & \multirow{5}{*}{$\begin{array}{l}\text { Institutionalized } \\
\text { inclusion of } \\
\text { organized } \\
\text { interests into the } \\
\text { policy-making }\end{array}$} & $\begin{array}{l}\text { Perceived level } \\
\text { of policy } \\
\text { coordination }\end{array}$ & 2.19 & 2.33 & 2.12 & 1.68 & 5 \\
\hline & & $\begin{array}{l}\text { Consultations } \\
\text { with political } \\
\text { parties }\end{array}$ & 2.08 & 1.28 & 1.9 & 1.68 & 5 \\
\hline & & $\begin{array}{l}\text { Consultations } \\
\text { with regulatory } \\
\text { authorities }\end{array}$ & 2.46 & 2.43 & 3.07 & 2.8 & 5 \\
\hline & & $\begin{array}{l}\text { Consultations } \\
\text { with present } \\
\text { government }\end{array}$ & 2.54 & 2.4 & 2.92 & 2.26 & 5 \\
\hline & & $\begin{array}{l}\text { Stability of } \\
\text { consultations } \\
\text { over time }\end{array}$ & 5 & 3 & 4 & 5 & 5 \\
\hline & \multirow[t]{2}{*}{$\begin{array}{l}\text { Consensus-oriented } \\
\text { relations between } \\
\text { organized interests }\end{array}$} & $\begin{array}{l}\text { Perception } \\
\text { of equal } \\
\text { opportunities }\end{array}$ & 2.2 & 2.62 & 2.42 & 2 & 5 \\
\hline & & $\begin{array}{c}\text { Consultations } \\
\text { with rivals }\end{array}$ & 2.26 & 1.58 & 2.21 & 1.96 & 5 \\
\hline \multirow[t]{3}{*}{ Structure } & $\begin{array}{l}\text { Regular, } \\
\text { institutionalized } \\
\text { interest } \\
\text { intermediation } \\
\text { body }\end{array}$ & $\begin{array}{l}\text { Existence of } \\
\text { tripartite } \\
\text { consultation } \\
\text { platform }\end{array}$ & 3 & 0 & 3 & 4 & 5 \\
\hline & $\begin{array}{l}\text { Transfer of policy- } \\
\text { making away from } \\
\text { parliament }\end{array}$ & $\begin{array}{l}\text { Level of } \\
\text { participation in } \\
\text { parliamentary } \\
\text { hearings }\end{array}$ & 2.93 & 3.59 & 2 & 3 & 5 \\
\hline & $\begin{array}{l}\text { Self-managed, peak } \\
\text { organizations of } \\
\text { capital and labour }\end{array}$ & $\begin{array}{l}\text { Existence of } \\
\text { representation } \\
\text { monopolies }\end{array}$ & 3 & 5 & 1 & 4 & 5 \\
\hline
\end{tabular}


two bodies for civil interest intermediation, both within the legislature with the National Council (Drzavni svet) and outside through the Economic and Social Council (ESC), but also high scores for consultations with regulatory authorities and a high perception of equal opportunities. As a further sign of corporatism, we also find strong interactions between healthcare employers and employees, the latter of which, in particular, reported a high level of policy coordination and exchange with the state. In other words, Slovenian healthcare policy-making is not characterized by unfettered competition among interest groups, rather its relatively consensual and non-political nature, as noted by numerous respondents, in particular several rivalling umbrella organizations (see Figure 5.10).

However, our data show that Slovenian healthcare is not as extremely corporatist as in Jahn's (2015) ranking for socio-economic issues. We would attribute this to the relatively weak position of patients, who are not organized in an umbrella organization in the main corporatist intermediation bodies. Hence, we would classify Slovenian healthcare as moderately corporatist, to the advantage of various healthcare trade unions and partial disadvantage to patients' organizations.

Again in contrast to Jahn's classification, the Czech Republic scores relatively close to Slovenia regarding healthcare. It constitutes an interesting case, because political parties, and not the parliament, are the main targets for interest groups (see also Roberts, 2009). As a sign of more corporatist policy-making, responding organizations, in particular umbrella organizations, report the highest frequency of consultations with rivalling organizations. Czech organizations also demonstrate the highest self-perceived influence of organized interests, whereby diffused interests (e.g. patients) and non-umbrellas see themselves as equally influential as umbrellas and representative medical profession associations. We also see patients' groups as being relatively fragmented and only occasionally involved in governmental consultations despite their declared strong influence. Czech healthcare organizations also aggregately report an intensification of consultations under the Babiš government. Therefore, it remains to be seen whether this will push the existing emerging moderately corporatist system with pluralist elements further towards the corporatist ideal type.

In Hungary, healthcare organizations seem to downright avoid the parliament and political parties. However, we would not interpret this as a sign of corporatism, rather as a reflection of the relatively closed nature of the political system (see Sata \& Karolewski, 2020). Along these lines, our data confirm that Hungary is the country in which healthcare organizations have the weakest ability to assert their interests (see Figure 5.9) and in which organizations least frequently engage with rivalling interests. Similarly to Slovenia, we see signs of representation monopolies of medical and healthcare professionals, who strongly engage in political coordination with the state, whereas patients (other than one disabilities' organization) are at a disadvantage. We would therefore classify Hungary somewhere between a one-sided, moderately corporatist and technocratic statist system of interest intermediation. 
Poland, the second least corporatist country in the list with less than half of possible points, is arguably the polar opposite of Hungary. Organized interests report good access to parliamentary bodies, in particular more "diffuse" groups such as patients and non-umbrellas. We also found no marked difference in the level of political coordination between government-subsidized and non-subsidized groups. There are also few signs of representation monopolies, although one large patients' organization and several smaller patients' organizations reported a high to moderate level of coordination with the state. Particularly noticeable is also the strong level of political coordination between several large employers' organizations and the state, political parties and regulatory authorities. Thus, on the one hand, interest organizations do form and shape the political process and political institutions appear to be much more accessible for traditionally weaker interest groups (e.g. patients) than in Hungary. We also see a higher level of coordination between organizational rivals than in Hungary. On the other hand, the Polish healthcare interest intermediation system remains organizationally fragmented and structurally less corporatist than Slovenia, as the Council for Social Dialogue (which still formally excludes patients' organizations) has only been recently introduced. Therefore, we would classify Polish healthcare interest intermediation as more pluralist with emerging corporatist structures, which according to our data enable a relative balance of concentrated (e.g. employers, medical profession) and diffuse interests (patients') in terms of asserting interests.

\section{Concluding remarks}

Exploring interest intermediation structures in post-communist policy-making posed numerous challenges. Besides a complex specification of the dependent variable, clear-cut categorization of organizations and identification of outliers in the given structures, we must cope with the reality that interest configurations may still differ within individual policy areas. For example, interest mobilization for hospital reform may play out entirely differently than reforms of patients' rights or the regulation of pharmaceuticals. Nevertheless, our respondents have provided us a wealth of information to map out the broader contours of the policy-making process. Our dual approach of aggregating scores for different groups of organizations for multiple dimensions of corporatism and later singling out organizations with or without quasi-representation monopolies enabled us to show both broader cross-country trends while also pinpointing country-specific interest intermediation networks.

Our data show that all four interest intermediation systems are roughly halfway towards fully fledged corporatism, with Slovenia in the lead, Hungary maintaining strong components of the statist paradigm and Poland and the Czech Republic being more pluralist. Our aggregated data also indicate that healthcare policy-making in all four countries is more consultative than in the past. Moreover, we found only little to no evidence for Olejnik's (2020) assumption of favouritism towards state-subsidized groups ("patronage corporatism"), as both state-funded and independently funded organizations declared similar 
perception of equal opportunities, influence and the frequency of consultations in Poland, Hungary and the Czech Republic. However, this claim should be subject to further research, with both aggregate data and individual case studies. Therefore, we encourage scholars to conduct case studies on individual reform processes not only to test our aggregate findings, but also to better understand the opportunities and limits for action of organized interests in the emerging corporatist arrangements. And most importantly, this would enable us to understand whether and when the demands and preferences of key stakeholders are translated into concrete policy changes.

\section{Notes}

1 Czech Republic 14th place, Slovenia 21st place, Poland 32nd place, Hungary 33rd place in European comparison regarding self-evaluations of healthcare outcomes.

2 Several were only applicable to economic policy (e.g. works councils, worker co-determination).

3 Due to data inconsistencies between countries, we did not include the pharmaceutical industry and medical devices manufacturers.

4 We stick to $20 \%$ as it constitutes a significant share of organizations' budgets, greatly affecting their capacity to act. Also, the $20 \%$ cut-off is a logical baseline due to the dispersion of our gathered data (i.e. few borderline cases such as $19 \%$ or $21 \%$ ).

5 We checked on the websites of tripartite bodies whether healthcare issues are dealt with frequently (approx. once a month) or seldom.

6 i.e. what share of all consultations the four to six largest groups (depending on country-spread) account for.

\section{References}

Albreht, T., Pribaković Brinovec, R., Jošar, D., Poldrugovac, M., Kostnapfel, T., Zaletel, M., Panteli, D., \& Maresso, A. (2016). Slovenia: Health system review, Health Systems in Transition 18(3):1-207.

Bohle, D. \& Greskovits, B. (2012). Capitalist Diversity on Europe's Periphery. Ithaca, NY: Cornell University Press.

Böhm, K., Schmid, A., Götze, R., Landwehr, C., \& Rothgang, H. (2013). Five types of OECD healthcare systems: Empirical results of a deductive classification, Health Policy 113(3), 258-269. doi: 10.1016/j.healthpol.2013.09.003

Bugaric, B. \& Kuhelj, A. (2015). Slovenia in crisis: A tale of unfinished democratization in East-Central Europe, Communist and Post-Communist Studies 48(4), 273-279. doi: 10.1016/j.postcomstud.2015.09.003

Christiansen, P. M., Nørgaard, A. S., Rommetvedt, H., Svensson, T., Thesen, G., \& Öberg, P. O. (2010). Varieties of democracy: Interest groups and corporatist committees in Scandinavian policy making, Voluntas 21(1), 22-40. doi: 10.1007/ s11266-009-9105-0

Crepaz, M., Hanegraaff, M., \& Salgado, R. S. (2019). A golden key can open any door? Public funding and interest groups' access, West European Politics (online first). doi: 10.1080/01402382.2019.1697592

Crepaz, M. \& Hanegraaff, M. (2020). The funding of interest groups in the EU: Are the rich getting richer?, Journal of European Public Policy 27(1), 102-121. doi: 10.1080/13501763.2019.1567572 
Dahl, R. A. (1967). Pluralist democracy in the United States: Conflict and consensus. Chicago, IL: Rand McNally.

Euro Health Consumer Index, Health Consumer Powerhouse. (2019). Online: https:// healthpowerhouse.com/media/EHCI-2018/EHCI-2018-report.pdf (Accessed 06 June 2020).

Falkner, G. (2003). The interprofessional social dialogue at European level: Past and future. In: B. Keller and H-W. Platzer (Eds.), Industrial Relations and European Integration. Developments and Prospects at EU-level, pp. 11-29, Aldershot: Ashgate.

Frączkiewicz-Wronka, A., Kowalska-Bobko, I., Sagan, A., \& Wronka-Pośpiech, M. (2019). The growing role of seniors councils in health policy-making for older people in Poland, Health Policy 123(10). doi: 10.1016/j.healthpol.2019.05.016

Gaal, P., Szigeti, S., Csere, M., Gaskins, M., Panteli, D., World Health Organization 2011 \& European Observatory on Health Systems and Policies, Brussels (2011). Hungary: Health system review, Health Systems in Transition 13(5), 1-266.

Gagliardi, A. (2016). The corporatism of fascist Italy: Between words and reality, Estudos Ibero-Americanos 42(2), 409-429.

Gerlinger, T. (2009). Der Wandel der Interessenvermittlung in der Gesundheitspolitik. In: B. Rehder, T. von Winter \& U. Willems (Eds.), Interessenvermittlung in Politikfeldern, pp. 33-51. Wiesbaden: VS Verlag.

Hanley, S. \& Vachudova, M. A. (2018). Understanding the illiberal turn: Democratic backsliding in the Czech Republic, East European Politics 34(3), 276-296.

Horváthová, B. \& Dobbins, M. (2019). Organised interests in the energy sector: A comparative study of the influence of interest groups in Czechia and Hungary, Politics and Governance 7(1), 139-151. doi: 10.17645/pag.v7i1.1784

Hunter, D. (2013). From Tribalism to corporatism: The continuing managerial challenge to medical dominance. In: D. Kelleher, J. Gabe \& G. Williams (Eds.), Challenging Medicine. London: Taylor and Francis. doi: 10.4324/9780203645635

Jacek, H. (1986). Pluralist and corporatist intermediation, activities of business interest associations, and corporate profits: Some evidence from Canada, Comparative Politics 18(4), 419-437. doi: 10.2307/421692

Jahn, D. (2016). Changing of the guard: Trends in corporatist arrangements in 42 highly industrialized societies from 1960 to 2010, Socio-Economic Review 14(1), 47-71. doi: 10.1023/A:1004385005999

Kafonkova, S. (2007). The Czech Medical Chamber and its Role in the Czech Political System, https://is.muni.cz/th/gixoo/?lang=en;zoomy_is=1 (Accessed 06 September 2020)

Kaminska, M. E. (2013). The missing dimension: A comparative analysis of healthcare governance in Central and Eastern Europe, Journal of Comparative Policy Analysis: Research and Practice 15(1), 68-86. doi: 10.1080/13876988.2013.765756

Kenworthy, L. (2003). Quantitative indicators of corporatism, International Journal of Sociology 33(3), 10-44. doi: 10.1080/15579336.2003.11770269

Korpi, W. (1983). The Democratic Class Struggle. London: Routledge \& Kegan Paul.

Kostelka, F. (2014). The state of political participation in post-communist democracies, Europe-Asia Studies 66(6), 945-968. doi: 10.1080/09668136.2014.905386

Müller-Jentsch, W. (1991). Konfliktpartnerschaft. Akteure und Institutionen industrieller Beziehungen. München: Hampp.

Navratil, J. \& Pospisil, M. (2014). Dreams of Civil Society Two Decades Later: Civic Advocacy in the Czech Republic. Brno: Masarykova univerzita. doi: 10.5817/CZ.MUNI. M210-6732-2014

Neumann, L. \& Toth, A. (2018). Hungarian unions under political and economic pressure. In: H. Dribbusch, S. Lehndorff, \& T. Schulten (Eds), Rough Waters. European Trade Unions in a Time of Crises, pp. 135-159. Brussels: European Trade Union Institute. 
Nicolaides, P. (2018). State Aid and EU funding: Are they compatible? Brussels: European Parliament. doi: 10.2861/66063

Olejnik, M. (2020). A new model of corporatism in states governed by populist political parties: The cases of Poland and Hungary, Czech Journal of Political Science 2(2020), 178-195. doi: 10.5817/PC2020-2-178

OECD (2019) Health at a glance. Paris: OECD.

Ost, D. (2000). Illusory corporatism in East Central Europe: Neoliberal tripartism and postcommunist class identities, Politics \& Society 28(4), 503-530. doi: 10.1177/ 0032329200028004004

Ost, D. (2011). Illusory corporatism ten years later, Warsaw Forum of Economic Sociology 2(3), 19-49.

Polak, P., Swiatkiewicz-Mosny, M., \& Wagner, A. (2019). Much Ado about nothing? The responsiveness of the healthcare system in Poland through patients' eyes, Health Policy 123(12), 1259-1266. doi: 10.1016/j.healthpol.2019.09.011

Rechel, B. \& McKee, M. (2009). Health reform in Central and Eastern Europe and the former Soviet Union, The Lancet 374(9696). doi: 10.1016/S0140-6736(09)61334-9

Roberts, A. (2009). The politics of healthcare reform in postcommunist Europe: The importance of access. Journal of Public Policy, 29(3), 305. doi:10.1017/S0143814X09990110

Sata, R. \& Karolewski, I. P. (2020). Caesarean politics in Hungary and Poland, East European Politics 36(2), 206-225. doi: 10.1080/21599165.2019.1703694

Schmitter, P. (1974). Still the century of corporatism? The Review of Politics 36(1), 85-131.

Schmitter, P. C. (1985). Neo-corporatism and the State. In: W. Grant (Ed.), The Political Economy of Corporatism, pp. 32-62. Basingstoke: Macmillian.

Schmitter, P. C. (1989). Corporatism is dead! Long live corporatism!, Government and Opposition 24(1). doi: 10.1111/j.1477-7053.1989.tb00107.x

Siaroff, A. (1999). Corporatism in 24 industrial democracies: Meaning and measurement, European Journal of Political Research 36(2), 175-205. doi: 10.1111/1475-6765.00467

Stanojević, M. (2011). Social pacts in Slovenia: Accommodation to the EMU Regime and the post-euro development, Warsaw Forum of Economic Sociology 2(3), 107-135.

Streeck, W. (1983). Between pluralism and corporatism: German business associations and the State, Journal of Public Policy 3(3), 265-283.

Streeck, W. \& Kenworthy, L. (2003). Theories and practices of neocorporatism. In: T. Janoski, R. Alford, A. Hicks \& M. Schwartz (Eds.), The Handbook of Political Sociology, pp. 441-460. Cambridge: Cambridge University Press. doi: 10.1017/ CBO9780511818059

Sześciło, D. (2017). Zmierzch decentralizacji? Instytucjonalny krajobraz opieki zdrowotnej w Europie po nowym zarzadzaniu pulicznym. Warszawa: Scholar.

Truman, D. B. (1951). The Governmental Process: Political Interests and Public Opinion. New York: Knopf.

Wendt, C., Tuba, I. A., \& Kaminska, M. E. (2013). Social health insurance without corporate actors: Changes in self-regulation in Germany, Poland and Turkey, Social Science \& Medicine 86, 88-95.

Wilson, F. (1983). French interest group politics: Pluralist or neocorporatist? The American Political Science Review 77(4), 895-910.

Woldendorp, J. (1997). Neo-corporatism and macroeconomic performance, Acta Politica 32(1), 49-79.

Woll, C. (2009) The demise of statism? In: A. M. Appleton, A. G. Mazur, \& S. Brouard (Eds.), The French Fifth Republic at Fifty: Beyond Stereotypes, 226-246. Basingstoke: Palgrave Macmillan. 
Ząbkowicz, A. (2014). Organized economic interests and European integration: The question of (neo)corporatism, Equilibrium. Quarterly Journal of Economics and Economic Policy 9(1), 7-20.

Zimmer, A. (1999). Corporatism revisited- the legacy of history and the German Nonprofit sector, Voluntas 10(1), 37-49. 